\title{
Thermodynamic characterization of single-stage spray dryers: Mass and energy balances for milk drying
}

\section{Cleuber Raimundo da Silva, Evandro Martins, Arlan Caldas Pereira Silveira, Moisés Simeão, Ariel Lessa Mendes, Ítalo Tuler Perrone, Pierre Schuck \& Antônio Fernandes de Carvalho}

To cite this article: Cleuber Raimundo da Silva, Evandro Martins, Arlan Caldas Pereira Silveira, Moisés Simeão, Ariel Lessa Mendes, Ítalo Tuler Perrone, Pierre Schuck \& Antônio Fernandes de Carvalho (2017): Thermodynamic characterization of single-stage spray dryers: Mass and energy balances for milk drying, Drying Technology, DOI: 10.1080/07373937.2016.1275675

To link to this article: http://dx.doi.org/10.1080/07373937.2016.1275675

Accepted author version posted online: 06

Feb 2017.

Published online: 06 Feb 2017.

Submit your article to this journal $[\pi$

Џ Article views: 52

View related articles

View Crossmark data \lceil 


\title{
Thermodynamic characterization of single-stage spray dryers: Mass and energy balances for milk drying
}

\author{
Cleuber Raimundo da Silva ${ }^{a}$, Evandro Martins ${ }^{a}$, Arlan Caldas Pereira Silveira ${ }^{a}$, Moisés Simeão, \\ Ariel Lessa Mendes ${ }^{a}$, Ítalo Tuler Perronea, Pierre Schuck ${ }^{b}$, and Antônio Fernandes de Carvalho \\ ${ }^{a}$ Food Science and Technology Department, Universidade Federal de Viçosa, Viçosa, MG, Brazil; 'bSTLO, Agrocampus Ouest, INRA, \\ Rennes, France
}

\begin{abstract}
Spray drying is an efficient unit operation applied in food drying that demands a high amount of energy compared to vacuum evaporation and membrane filtration. The objective of this work was to present a mathematical model-like basis for the construction of mass and energy balances. For this purpose, two lab-scale single spray dryers in milk drying with different evaporative capacities have been used as example. The values of the absolute humidity, mass and energy losses, energetic specific consumption (ESC), and the efficiency of the process were obtained by calculations developed in this work. The mathematical model was valid for the evaluation of mass and energy losses, and it allowed us to compare the efficiencies of spray dryers with different designs. From this model, it is possible to compare different drying processes and dryers.
\end{abstract}

\section{ARTICLE HISTORY}

Received 30 August 2016

Revised 19 December 2016

Accepted 19 December 2016

\section{KEYWORDS}

Energy consumption; mass and energy balances; mathematical modeling; spray drying

\section{Introduction}

In 2014, the global milk production was 802 million tons, with an increase in $3.3 \%$ compared to the production in $2013 .^{[1]}$ Since milk is perishable, the surplus production is designated for the fabrication of dehydrated dairy products to improve its conservation over time. However, in 2014, approximately 50 million tons of milk were designated for the production of whole milk powder. ${ }^{[1]}$

In freeze-drying, the energy consumption is from 5,000 to $10,000 \mathrm{KWh} \mathrm{t}^{-1}$ of removed water and in drum drying is from 300 to $1,000 \mathrm{KWh} \mathrm{t}^{-1}$ of removed water. $^{[2-5]}$ Although there are advantages to both techniques, spray drying is still the most used in the dairy industry for milk powder production. The energetic consumption of spray drying is approximately 10-fold lower than that of freeze-drying, and contrary to the drum drying technique, the product does not reach high temperatures during water evaporation. ${ }^{[6,7]}$

In spray drying, milk is pulverized in droplets inside a drying tower where the product comes in contact with heated air. Due to an increase in the surface contact between the milk and air, water is evaporated quickly without excessive heat treatment, during this operation. ${ }^{[8]}$ Thus, milk powder with low water activity $\left(a_{\mathrm{w}}=0.18-0.22\right)$ is formed without excessive losses of the nutritional and sensorial characteristics of milk. ${ }^{[9]}$
Although spray drying is largely applied to the manufacturing of dried dairy products on an industrial scale, the energy consumption of this technique is still considerable (1,000-2,000 $\mathrm{KWh} \mathrm{t}^{-1}$ removed water). ${ }^{[4]}$ Thus, the appropriate operation of spray dryer should be performed to reduce the cost of production and improve the quality of milk powder. ${ }^{[8,10-12]}$ Sustainability issues and reduction of energy costs are the next challenge for the dairy industry. ${ }^{[13,14]}$

The final cost of the milk powder formulas is associated with the losses (mass and energy) that occur during the drying process. ${ }^{[15]}$ The mass losses are related to the adherence of milk particles on the internal surface of the drying tower or to transport of the particles by the air flow. In this study, the thermal energy losses can be estimated as the sum of dissipated energy through the equipment surface and the energy not used in the conversion of water to vapor.

The mass and energy balance is a mathematical tool that allows the evaluation of the mass and energy losses in the process of spray dryer dehydration. In addition, this tool makes possible the estimation of the production cost, the comparison of the efficiency of different equipment, and the determination of the amount of energy necessary to evaporate $1 \mathrm{~kg}$ of water from the product. The application of the mathematical tool in 
dairy industry ensures the better control of the dairy powder technology. ${ }^{[16,17]}$

In this paper, we present a mathematical basis for construction of the mass and energy balance for the milk drying process using single-stage spray dryer equipment. It aims to create a protocol that will work as a support for industries that plan to evaluate the production efficiency of their spray dryers. For this, we will use as an example the milk drying in two lab-scale spray dryers with different evaporative capacities.

\section{Materials and methods}

The experiments were performed using two lab-scale single-stage spray dryers. Table 1 summarizes the principal characteristics of each equipment.

The relative humidities and temperatures were measured as presented in the scheme (Figs. 1-3) using a thermohygrometer (Rotronic, Hydropalm). The air velocity measurements were performed using an anemometer (Air Velocity Transducers, model TSI Alnor 84455) whose catheter was introduced in five different positions of the section of straight cylindrical ducts. ${ }^{[18]}$

\section{Validation of mathematical models and evaluation of optimal efficiency of operation of spray dryers}

\section{Evaporation of water}

Water heated at $40^{\circ} \mathrm{C}$ was injected into SD1 or SD2 where it was evaporated in the presence of heated inlet air at $165 \pm 5^{\circ} \mathrm{C}$. The flow rate of the water was adjusted to maintain the outlet air temperature at approximately $90 \pm 3^{\circ} \mathrm{C}$. The process was executed with three repetitions on different days.

\section{Drying of milk}

Concentrated whole milk ( $40 \%$ dry material) at $40^{\circ} \mathrm{C}$ was injected into SD1 or SD2 where it was dehydrated with inlet air at $165 \pm 5^{\circ} \mathrm{C}$. The flow rate of milk was adjusted to maintain the outlet air temperature at approximately $95 \pm 3^{\circ} \mathrm{C}$ to SD1 and $90 \pm 3^{\circ} \mathrm{C}$ to SD2.

All experiments were performed with three repetitions on different days.

Table 1. Characteristics of spray dryers.

\begin{tabular}{llcccc}
\hline Spray dryer & Atomizer & $\begin{array}{c}\text { Evaporative capacity } \\
\left(\mathrm{kg} \mathrm{water} \cdot \mathrm{h}^{-1}\right)\end{array}$ & Superficial area $\left(\mathrm{m}^{2}\right)$ & Model & Fabricator \\
\hline SD1 & Pressure nozzle & 1 & 0.51 & MSD 1.0 & Labmaq, Brazil \\
SD2 & Rotating disk & 20 & 7.54 & Minor production & Niro Atomizer, GEA, Germany \\
\hline
\end{tabular}

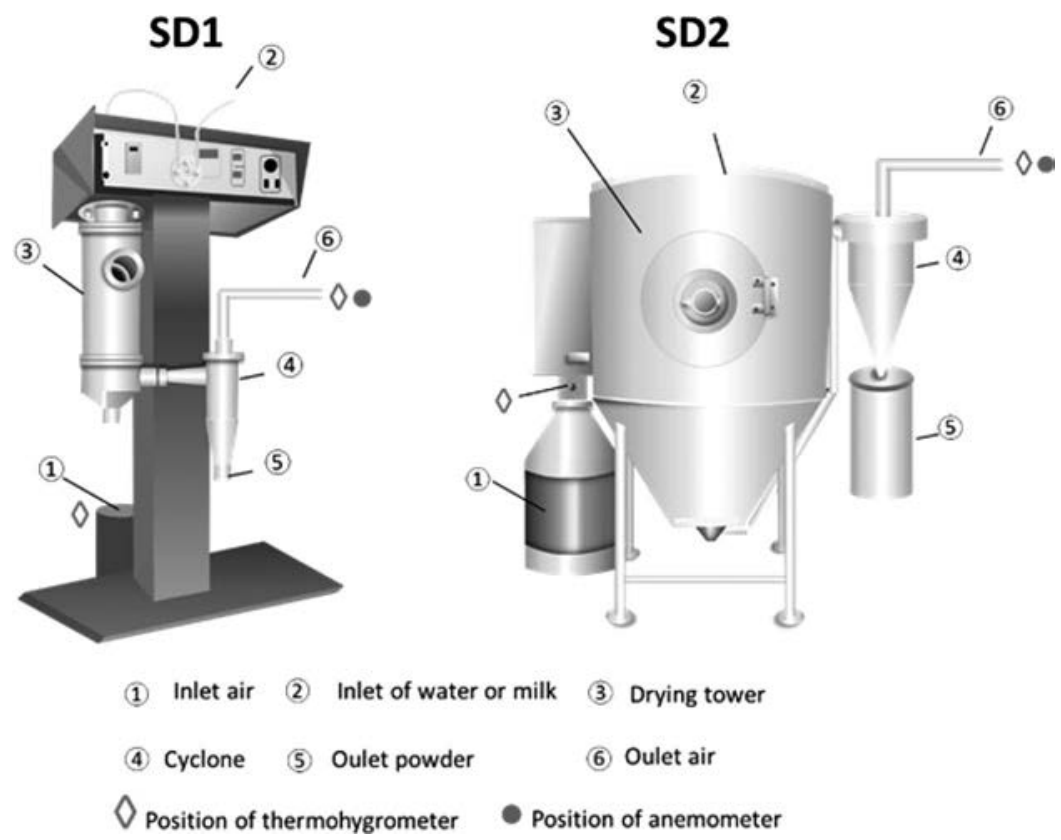

Figure 1. Scheme of single-stage spray dryers. SD1: Labmaq, Brazil; SD2: Niro Atomizer, GEA, Germany. 
Balance of mass-energy using water evaporation as reference

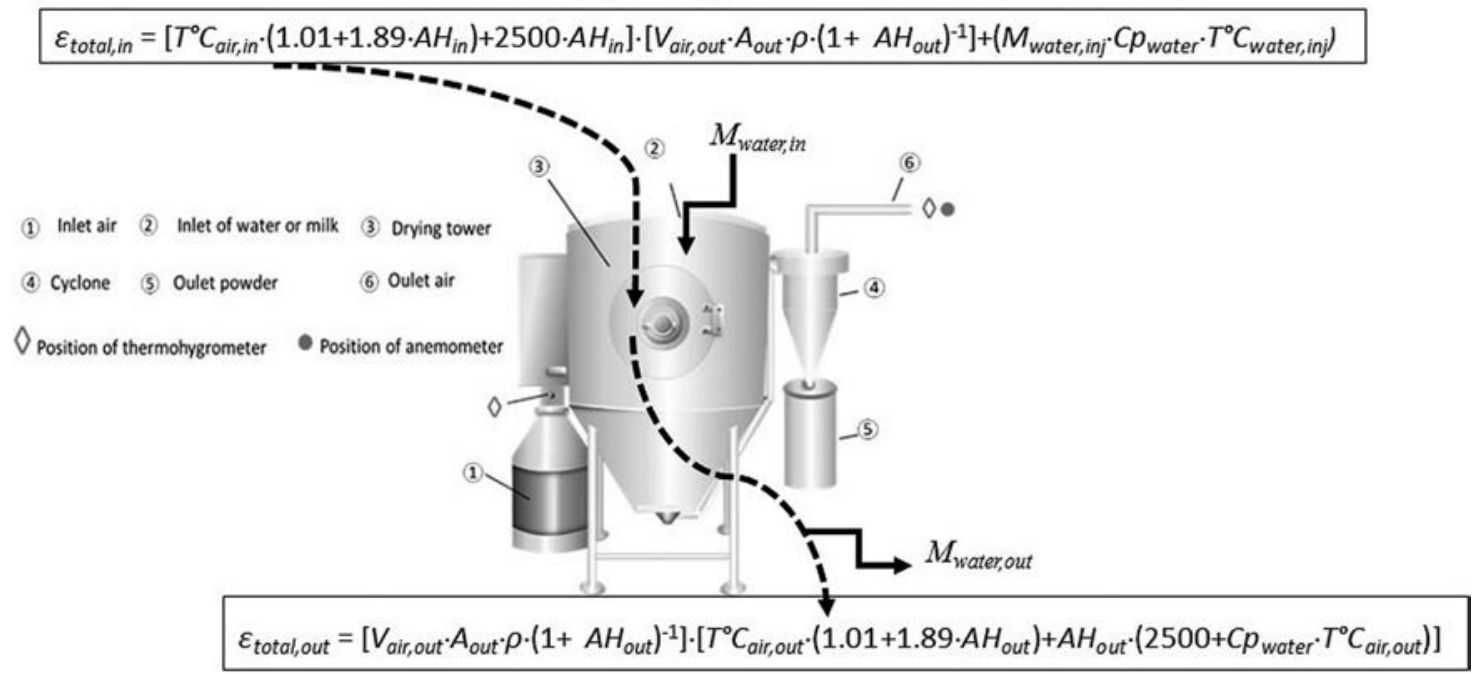

Input parameters:

$T^{\circ} \mathrm{C}_{\text {air, in }}=$ inlet air temperature $\left({ }^{\circ} \mathrm{C}\right)$

$A H_{\text {in }}=$ inlet air absolute humidity $\left(\mathrm{kg}\right.$ water $\left.\cdot \mathrm{kg} \mathrm{dry} \mathrm{air}^{-1}\right)$

$V_{\text {air,out }}=$ outlet air velocity $\left(\mathrm{m} \cdot \mathrm{h}^{-1}\right)$

$A_{\text {out }}=$ area of the transversal section of outlet tubing $\left(\mathrm{m}^{2}\right)$

$M_{\text {woterinj }}=$ water injected into spray-dryer $\left(\mathrm{kg} \cdot \mathrm{h}^{-1}\right)$

$T^{\circ} C_{\text {water, }, \text { inj }}=$ temperature of injected water $\left({ }^{\circ} \mathrm{C}\right)$

$A H_{\text {out }}=$ outlet air absolute humidity ( $\mathrm{kg}$ water $\cdot \mathrm{kg}$ dry air $\left.^{-1}\right)$

$T^{\circ} \mathrm{C}_{\text {air out }}=$ outlet air temperature $\left({ }^{\circ} \mathrm{C}\right)$
Assumptions:

$\varepsilon_{\text {total, in }}=\varepsilon_{\text {total,out }}$ (conservation of energy)

$\varepsilon_{\text {total,in }}=$ inlet energy $\left(\mathrm{kJ} \cdot \mathrm{h}^{-1}\right)$

$\varepsilon_{\text {total,our }}=$ outlet energy $\left(\mathrm{kJ} \cdot \mathrm{h}^{-1}\right)$

$M_{\text {water, in }}=M_{\text {water, ouf }}$ (conservation of mass)

$M_{\text {water, in }}=$ mass of injected water $\left(\mathrm{kg} \cdot \mathrm{h}^{-1}\right)$

$M_{\text {water, oud }}=$ mass of water in the vapor form $\left(\mathrm{kg} \cdot \mathrm{h}^{-1}\right)$

$\rho=$ air density $\left(1.0 \mathrm{~kg} \cdot \mathrm{m}^{-3}\right)$

$C p_{\text {woter }}=$ specific heat of water $\left(4.18 \mathrm{~kJ} \cdot{ }^{\circ} \mathrm{C}^{-1} \cdot \mathrm{kg}^{-1}\right)$

Figure 2. Balance of mass-energy using water evaporation as reference.

\section{Balance of mass-energy using milk}

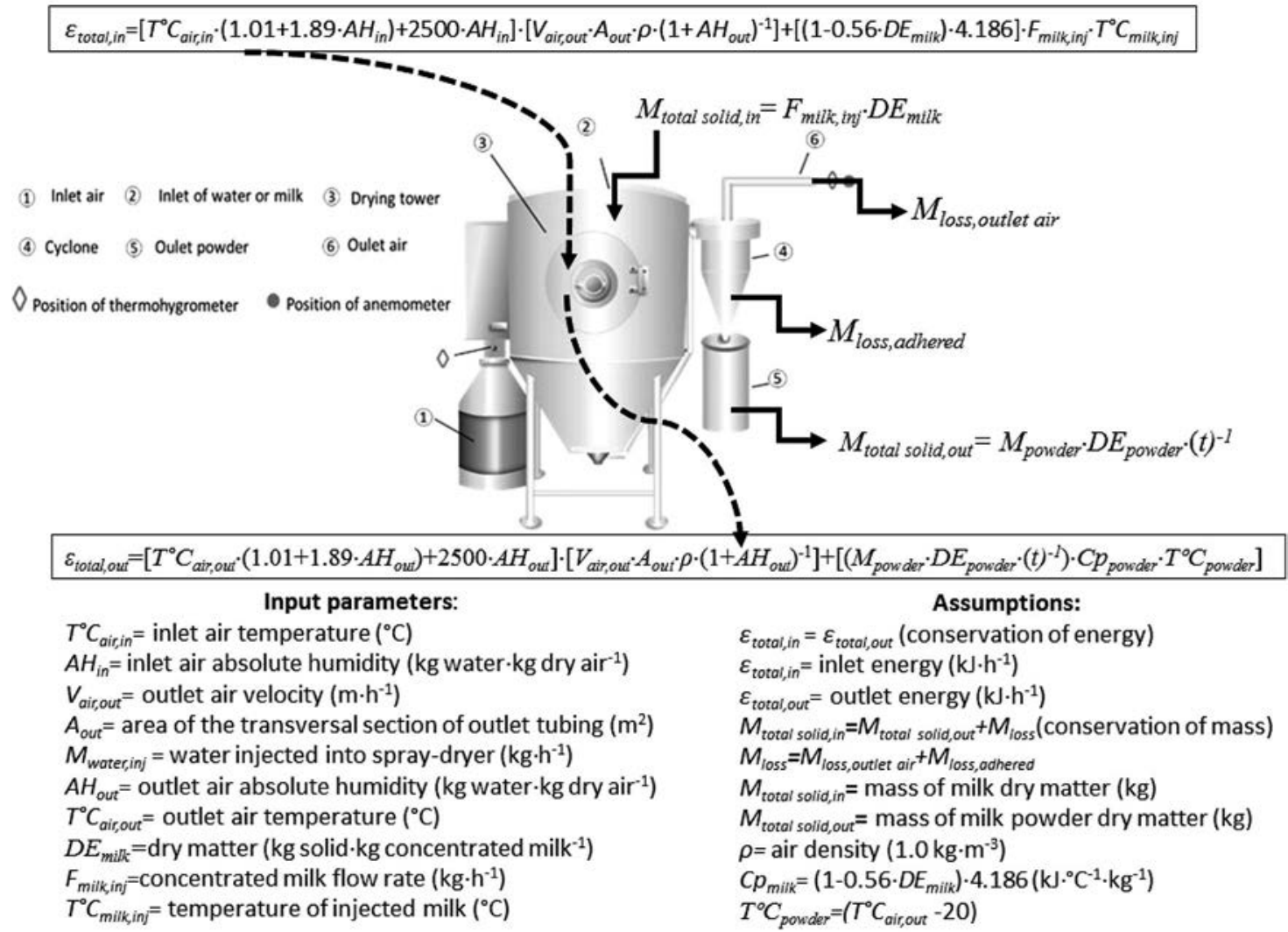

Figure 3. Balance of mass-energy using milk. 


\section{Results and discussion}

\section{Balance of mass-energy using water evaporation as reference}

\section{Mass balance for water evaporation: Validation of the mathematical model}

To create a mathematical model for the evaporation process in spray dryers, the simpler condition will be tested. Before promoting the drying of dairy products, simple water evaporation will be performed. This means that in the equipment inlet, water will be injected, and only vapor will be recovered in the outlet of the spray dryers.

During the process of water evaporation, all water entering the equipment is assumed be converted to vapor, i.e., no mass loss occurs. Thus, the mass balance under this condition has a finality to verify the accuracy of the mathematical equations and ensure that the measurements with the thermohygrometer and anemometer (temperature, relative humidity, and air velocity) are consistent.

The first step of mass balance consists of calculating the flow rate of humid air $\left(F_{\text {humid air; }} \mathrm{kg}\right.$ air $\left.^{-1}\right)$, which is similar in both the input and output of the equipment. However, this parameter is preferably calculated from the outlet data, since in some spray dryers, the air can enter by small slots or holes close to the atomizer, thus resulting in underestimation of the data.

$F_{\text {humid air }}$ is calculated from the air velocity measured by an anemometer in the outlet $\left(V_{\text {air,out }} \mathrm{m} \mathrm{h}^{-1}\right)$, the area of the transversal section of outlet tubing $\left(A_{\text {out }} ; \mathrm{m}^{2}\right)$, and the air density $\left(\rho ; \mathrm{kg} \mathrm{m}^{-3}\right)$ :

$$
F_{\mathrm{h}, \text { air }}=V_{\mathrm{a}, \text { out }} A_{\text {out }} \rho
$$

where $\rho$ is assumed be constant and equal to $1.0 \mathrm{~kg} \mathrm{~m}^{-3}$.

The second step consists of determining the mass of water contained in the air $\left(M_{\text {water,air out }} ; \mathrm{kg} \mathrm{h}^{-1}\right) \cdot M_{\text {water, }}$ air out can be estimated from the absolute humidity of the outlet air $\left(A H_{\text {out }} ; \mathrm{kg}\right.$ water $\mathrm{kg}$ dry $\left.\mathrm{air}^{-1}\right)$ and the flow rate of humid air (Eq. 2). ${ }^{[19]}$

$$
M_{\text {wa }, \text { out }}=F_{\mathrm{h}, \text { air }} A H_{\text {out }}\left(1+A H_{\text {out }}\right)^{-1}
$$

The dry air flow rate $\left(F_{\text {dry,air }} ; \mathrm{kg} \mathrm{h}^{-1}\right)$ is calculated by subtraction of the flow rate of humid air and the water mass contained in the outlet air. By combining Eqs. (1) and (2), $F_{\text {dry,air }}$ can be written as:

$$
\begin{aligned}
& F_{\mathrm{d}, \text { air }}=F_{\mathrm{h}, \text { air }}-M_{\mathrm{wa}, \text { out }} \\
& F_{\mathrm{d}, \text { air }}=V_{\mathrm{a}, \text { out }} A_{\text {out }} \rho\left(1+A H_{\text {out }}\right)^{-1}
\end{aligned}
$$

The mass of water presented in the inlet air $\left(M_{\text {water air,in }} ; \mathrm{kg} \mathrm{h}^{-1}\right)$ is the product of $F_{\text {dry,air }}$ and the absolute humidity of inlet air $\left(A H_{\text {in }}, \mathrm{kg}\right.$ water $\mathrm{kg}$ dry $\left.\mathrm{air}^{-1}\right)$ :

$$
\begin{aligned}
& M_{\mathrm{w}, \text { in }}=F_{\mathrm{d}, \text { air }} A H_{\text {in }} \\
& M_{\mathrm{w}, \text { in }}=A H_{\mathrm{in}} V_{\mathrm{a}, \text { out }} A_{\text {out }} \rho\left(1+A H_{\text {out }}\right)^{-1}
\end{aligned}
$$

The total water mass entering the equipment $\left(M_{\text {total water,in }} ; \mathrm{kg} \mathrm{h}^{-1}\right)$ is calculated by addition of the water injected into spray dryer $\left(M_{\text {water, inj }} ; \mathrm{kg} \mathrm{h}^{-1}\right)$ and the amount of water carried from the inlet air $\left(M_{\text {water air, in }} ; \mathrm{kg} \mathrm{h}^{-1}\right)$ :

$$
\begin{aligned}
& M_{\mathrm{tw}, \text { in }}=M_{\mathrm{w}, \text { inj }}+M_{\mathrm{wa}, \text { in }} \\
& M_{\mathrm{tw}, \text { in }}=M_{\mathrm{w}, \text { inj }}+\left[A H_{\mathrm{in}} V_{\mathrm{a}, \text { out }} A_{\text {out }} \rho\left(1+A H_{\mathrm{out}}\right)^{-1}\right]
\end{aligned}
$$

In the outlet, all water mass evaporated is eliminated by air in the vapor form. The total mass of evaporated water $\left(M_{\text {total }}\right.$ water,out; $\left.\mathrm{kg} \mathrm{h}^{-1}\right)$ is determined by combination of Eqs. (1) and (2):

$$
\begin{gathered}
M_{\mathrm{tw}, \text { out }}=M_{\mathrm{w}, \text { out }}=F_{\mathrm{d}, \mathrm{air}} A H_{\text {out }} \\
M_{\mathrm{tw}, \text { out }}=V_{\mathrm{a}, \text { out }} A_{\text {out }} \rho A H_{\text {out }}\left(1+A H_{\text {out }}\right)^{-1}
\end{gathered}
$$

The final step for mass balance $\left(\Delta_{\text {mass }} ; \mathrm{kg} \mathrm{h}^{-1}\right)$ is performed by subtracting the total of the water exiting the spray dryer ( $M_{\text {total water,out }}$ Eq. 7$)$ and the water total mass entering the equipment $\left(M_{\text {total water,in; }}\right.$; Eq. 5), thus:

$$
\Delta_{\text {mass }}=M_{\mathrm{tw}, \text { out }}-M_{\mathrm{tw}, \text { in }}
$$

\begin{tabular}{|c|c|c|c|c|c|c|c|c|}
\hline \multirow[b]{2}{*}{ Equipment } & \multicolumn{3}{|c|}{ Inlet parameters } & \multicolumn{4}{|c|}{ Outlet parameters } & \multirow[b]{2}{*}{$\begin{array}{c}\Delta_{\text {mass }} \\
\left(\mathrm{kg} \mathrm{h}^{-1}\right)\end{array}$} \\
\hline & $\begin{array}{c}A H_{\mathrm{in}}{ }^{*} \\
\left(\mathrm{~kg}_{\text {water }} \cdot \mathrm{kg}_{\text {dry air }}^{-1}\right)\end{array}$ & $\begin{array}{c}M_{\text {water,inj }}{ }^{*} \\
\left(\mathrm{~kg} \mathrm{~h}^{-\mathrm{T}}\right)\end{array}$ & $\begin{array}{l}\text { Mtotal water,in } \\
\left(\mathrm{kg} \mathrm{h}^{-1}\right)\end{array}$ & $\begin{array}{l}A_{\text {out }} \\
\left(\mathrm{m}^{2}\right)\end{array}$ & $\begin{array}{c}A H_{\text {out }}^{*} \\
\left(\mathrm{~kg}_{\text {water }} \cdot \mathrm{kg}_{\text {dry air }}^{-1}\right)\end{array}$ & $\begin{array}{l}V_{\text {air,out }}^{*} \\
\left(\mathrm{~m} \mathrm{~h}^{-1}\right)\end{array}$ & $\begin{array}{c}\text { Mtotal water,out } \\
\left(\mathrm{kg} \mathrm{h}^{-1}\right)\end{array}$ & \\
\hline SD1 & $1.63 \times 10^{-} 2$ & $8.30 \times 10^{-1}$ & $1.69 \times 10^{0}$ & $9.62 \times 10^{-4}$ & $3.20 \times 10^{-2}$ & $5.65 \times 10^{4}$ & $1.69 \times 10^{0}$ & 0.00 \\
\hline SD2 & $1.34 \times 10^{-2}$ & $7.68 \times 10^{0}$ & $1.27 \times 10^{1}$ & $7.24 \times 10^{-3}$ & $3.39 \times 10^{-2}$ & $5.35 \times 10^{4}$ & $1.27 \times 10^{1}$ & 0.00 \\
\hline
\end{tabular}

Table 2 shows the parameters measured in the spray dryers during water evaporation and mass balance of process.

Using the mathematical treatment presented above, the mass balance $\left(\Delta_{\text {mass }}=0\right)$ is according to the theoretical assumption for water evaporation. In other words, the mathematical model, as well as the measurements performed with the anemometer and the thermohygrometer, was consistent with the reality of the drying

Table 2. Inlet and outlet parameters used in mass balance for water evaporation.

*Measurement performed in triplicate with standard variation inferior to $5 \%$. 
procedure. In our case, the mass balance was equal to zero, but some variations can be found due to errors in measurements and numeric rounding.

\section{Energy balance for water evaporation}

Since the water is in a completely free state, meaning that it is not linked to any substrate, the energy balance has a finality, permitting the determination of the minimal energy consumed by each equipment. This approach allows a comparison of the energetic performance of spray dryers with different evaporative capacities and designs without the interference of the properties of a food matrix. In food, the water may be linked or partially linked to the main food components. This water does not act as a solvent; rather, it presents resistance to mechanical strength in addition to low molecular mobility and different dielectric properties of free water, thus making the drying process more difficult. $^{[20]}$

In addition to mass balance, in the energy balance, the calculation can be divided into energy entering and leaving the spray dryer.

The total inlet energy $\left(\varepsilon_{\text {total,in }} ; \mathrm{kJ} \mathrm{h}^{-1}\right)$ is calculated by the addition of energy of hot inlet air $\left(\varepsilon_{\text {air,in }} ; \mathrm{kJ} \mathrm{h}^{-1}\right)$ and the energy of water entering the drying tower $\left(\varepsilon_{\text {water,in }} ; \mathrm{kJ} \mathrm{h}^{-1}\right)$ :

$$
\varepsilon_{\mathrm{t}, \mathrm{in}}=\varepsilon_{\mathrm{a}, \text { in }}+\varepsilon_{\mathrm{w}, \text { in }}
$$

The energy of the hot air inlet $\left(\varepsilon_{\text {air,in }}\right)$ is given by multiplication between the air enthalpy $\left(E_{\mathrm{air}, \mathrm{in}} ; \mathrm{kJ} \mathrm{kg}^{-1}\right)$ and flow rate of the air (from Eq. 3):

$$
\varepsilon_{\mathrm{a}, \text { in }}=E_{\mathrm{a}, \text { in }} F_{\mathrm{d}, \mathrm{air}}
$$

where $E_{\text {air,in }}$ is calculated from the temperature $\left(T^{\circ} \mathrm{C}_{\text {air,in }}\right)$ and the absolute humidity $\left(A H_{\text {in }}\right)$ of the inlet air:

$$
E_{\mathrm{a}, \text { in }}=T_{\mathrm{a}, \text { in }}\left(1.01+1.89 A H_{\mathrm{in}}\right)+2500 A H_{\mathrm{in}}
$$

By substituting Eqs. (3) and (11) into (10), the $\varepsilon_{\text {air,in }}$ can be rewritten as:

$$
\begin{aligned}
\varepsilon_{\mathrm{a}, \text { in }}= & {\left[T_{\mathrm{a}, \text { in }}\left(1.01+1.89 A H_{\text {in }}\right)+2500 A H_{\text {in }}\right] } \\
& {\left[V_{\mathrm{a}, \text { out }} A_{\text {out }} \rho\left(1+A H_{\text {out }}\right)^{-1}\right] }
\end{aligned}
$$

The second term of Eq. (9), i.e., the energy of water entering into the drying tower $\left(\varepsilon_{\text {water,in }}\right)$, is determined from the product of flow rate of water injected into spray dryer $\left(M_{\text {water,inj; }} \mathrm{kg} \mathrm{h}^{-1}\right)$, specific heat $\left(C p_{\text {water }}=\right.$ $\left.4.18 \mathrm{~kJ} \cdot{ }^{\circ} \mathrm{C}^{-1} \cdot \mathrm{kg}^{-1}\right)$, and its temperature $\left(T^{\circ} \mathrm{C}_{\text {water,inj }}\right)$ :

$$
\varepsilon_{\mathrm{t}, \text { in }}=M_{\mathrm{w}, \mathrm{inj}} C_{\mathrm{pw}} T_{\mathrm{w}, \mathrm{inj}}
$$

By substitution of Eqs. (12) and (13) into Eq. (9), the total energy entering the system can be understood as:

$$
\begin{gathered}
\varepsilon_{\mathrm{t}, \text { in }}=\left[T_{\mathrm{a}, \text { in }}\left(1.01+1.89 A H_{\mathrm{in}}\right)+2500 A H_{\mathrm{in}}\right] \\
{\left[V_{\mathrm{a}, \text { out }} A_{\text {out }} \rho\left(1+A H_{\text {out }}\right)^{-1}\right]+M_{\mathrm{w}, \text { inj }} C_{\mathrm{pw}} T_{\mathrm{w}, \text { inj }}}
\end{gathered}
$$

The total outlet energy $\left(\varepsilon_{\text {total,out }} ; \mathrm{kJ} \mathrm{h}^{-1}\right)$ is deduced analogously to that demonstrated for $\varepsilon_{\text {total,in }}$ using the outlet data. Therefore, $\varepsilon_{\text {total,out }}$ can be written as:

$$
\begin{aligned}
& \varepsilon_{\mathrm{t}, \text { out }}=\varepsilon_{\mathrm{a}, \text { out }}+\varepsilon_{\mathrm{w}, \text { out }} \\
& \varepsilon_{\mathrm{t}, \text { out }}=\left[\mathrm{T}_{\mathrm{a}, \text { out }}\left(1.01+1.89 A H_{\text {out }}\right)+2500 A H_{\text {out }}\right] \\
& \quad\left[V_{\mathrm{a}, \text { out }} A_{\text {out }} \rho\left(1+A H_{\text {out }}\right)^{-1}\right]+M_{\mathrm{tw}, \text { out }} C p_{\mathrm{w}} \mathrm{T}_{\mathrm{a}, \text { out }}
\end{aligned}
$$

where $M_{\text {total water,out }}\left(\mathrm{kg} \mathrm{h}^{-1}\right)$ denotes the mass of water in the vapor form.

Substituting Eq. (6) into (15) yields:

$$
\begin{aligned}
\varepsilon_{\mathrm{t}, \text { out }}= & {\left[V_{\mathrm{a}, \text { out }} A_{\text {out }} \rho\left(1+A H_{\text {out }}\right)^{-1}\right] } \\
& \times\left[T_{\mathrm{a}, \text { out }}\left(1.01+1.89 A H_{\text {out }}\right)+A H_{\text {out }}(250\right. \\
& \left.\left.+C p_{\mathrm{w}} \mathrm{T}_{\mathrm{a}, \text { out }}\right)\right]
\end{aligned}
$$

From the inlet $\left(\varepsilon_{\text {total,in }}\right.$; Eq. 14$)$ and outlet $\left(\varepsilon_{\text {total,out; }}\right.$ Eq. 16) data, it is possible to determine the energy loss $\left(\varepsilon_{\text {loss }} ;\right.$ in percentage):

$$
\varepsilon_{\text {loss }}=\left(1-\frac{\varepsilon_{\mathrm{t}, \text { out }}}{\varepsilon_{\mathrm{t}, \text { in }}}\right) \times 100
$$

This parameter allows evaluation of the amount of energy that is dissipated from spray dryer or simply wasted during drying process. Another parameter that allows comparison of the drying efficiency of different equipment is the (ESC; $\mathrm{kJ} \mathrm{kg}^{-1}$ evaporated water), which is defined as the amount of energy necessary to evaporate $1 \mathrm{~kg}$ of water: ${ }^{[21]}$

$$
\begin{aligned}
\mathrm{ESC} & =\frac{\varepsilon_{\mathrm{t}, \text { in }}}{M_{\mathrm{tw}, \text { out }}} \\
\mathrm{ESC} & =\frac{\varepsilon_{\mathrm{t}, \text { in }}}{\left[V_{\mathrm{a}, \text { out }} A_{\text {out }} \rho A H_{\text {out }}\left(1+A H_{\text {out }}\right)^{-1}\right]}
\end{aligned}
$$

The energetic efficiency of the process ( $\left.\varepsilon_{\text {efficiency }}\right)$ can be estimated by division of the ESC value (Eq. 17) by the latent heat of vaporization of water $\left(L_{\text {water }}=\right.$ $\left.2337.46 \mathrm{~kJ} \mathrm{~kg}^{-1}\right)$ :

$$
\varepsilon_{\mathrm{ef}}=\frac{\mathrm{ESC}}{L_{\mathrm{w}}}
$$

This allows an estimation of how much more energy was expended in relation to the theoretical value $\left(L_{\text {water }}\right)$. The higher the value of $\varepsilon_{\text {efficiency, }}$ the lower is the efficiency of drying process.

All parameters necessary to calculate the energetic loss $\left(\varepsilon_{\text {loss }}\right)$, ESC, and the energetic efficiency of the 
Table 3. Energetic balance for water evaporation.

\begin{tabular}{|c|c|c|c|c|c|c|c|c|}
\hline \multirow[b]{2}{*}{ Equipment } & \multicolumn{3}{|c|}{ Inlet data } & \multicolumn{2}{|c|}{ Outlet data } & \multirow[b]{2}{*}{$\varepsilon_{\text {loss }}(\%)$} & \multirow[b]{2}{*}{ ESC $\left(\mathrm{kJ} \mathrm{kg}^{-1}\right)$} & \multirow[b]{2}{*}{$\varepsilon_{\text {efficiency }}$} \\
\hline & $T^{\circ} \mathrm{C}_{\text {air,in }} *\left({ }^{\circ} \mathrm{C}\right)$ & $T^{\circ} \mathrm{C}_{\text {water,inj }}{ }^{*}\left({ }^{\circ} \mathrm{C}\right)$ & $\varepsilon_{\text {total,in }}\left(\mathrm{kJ} \mathrm{h}^{-1}\right)$ & $T^{\circ} \mathrm{C}_{\text {air, out }}{ }^{*}\left({ }^{\circ} \mathrm{C}\right)$ & $\varepsilon_{\text {total,out }}\left(\mathrm{kJ} \mathrm{h}^{-1}\right)$ & & & \\
\hline SD1 & $1.63 \times 10^{2}$ & $4.00 \times 10^{1}$ & $1.12 \times 10^{4}$ & $9.12 \times 10^{1}$ & $9.89 \times 10^{3}$ & 12.24 & $6.70 \times 10^{3}$ & 2.87 \\
\hline SD2 & $1.70 \times 10^{2}$ & $4.00 \times 10^{1}$ & $7.98 \times 10^{4}$ & $8.82 \times 10^{1}$ & $7.51 \times 10^{4}$ & 8.76 & $5.93 \times 10^{3}$ & 2.55 \\
\hline
\end{tabular}

*Measurement performed in triplicate with standard variation inferior to $5 \%$.

process $\left(\varepsilon_{\text {efficiency }}\right)$ are displayed in Tables 2 and 3 for SD1 and SD2.

The heat balance shows a difference between inputs and outputs $\left(\varepsilon_{\text {loss }}\right)$ of approximately 12 and $9 \%$ for SD1 and SD2, respectively. This difference is related to the heat loss from not insolated parts of equipment and probable errors of calculation and measurements. Although SD2 shows a superficial area $\left(7.54 \mathrm{~m}^{2}\right)$ larger than SD1 $\left(0.51 \mathrm{~m}^{2}\right)$, the noninsulated parts of each equipment present 100 and 20\%, respectively. Additionally, SD2 shows the best value for ESC and $\varepsilon_{\text {efficiency, }}$ indicating greater use of energy by this equipment.

The equipment (SD1 and SD2) presented high energy loss compared to industrial spray dryers, which present losses between 3 and $5 \% .{ }^{[3]}$. In addition to the heat isolation capacity, the size of equipment may influence the energy loss and efficiency. ${ }^{[21]}$

\section{Milk drying}

In the previous section, the mathematical model and the measurements performed using an anemometer and a thermohygrometer were validated by mass balance. Furthermore, the ideal energetic operation of the spray dryers was evaluated using an energetic balance for water evaporation.

In this section, the mathematical approach used for water evaporation in spray dryer will be used for balance of mass and energy for milk drying.

\section{Mass balance for milk drying}

The total content of solids entering into drying tower $\left(M_{\text {total solid,in }} ; \mathrm{kg} \mathrm{h}^{-1}\right)$ is given by multiplication between the flow rate of concentrated milk $\left(F_{\text {milk,inj; }} \mathrm{kg} \mathrm{h}^{-1}\right)$ and its dry extract $\left(D E_{\text {milk}}, \mathrm{kg}_{\text {solid }} \cdot \mathrm{kg}_{\text {concentrated milk }}^{-1}\right)$ :

$$
M_{\mathrm{ts}, \text { in }}=F_{\mathrm{m}, \mathrm{inj}} \mathrm{TS}_{\mathrm{m}}
$$

In the outlet, the amount of solids after drying $\left(M_{\text {total solid,out; }} \mathrm{kg} \mathrm{h}^{-1}\right)$ is calculated from the amount of powder milk recovered ( $M_{\text {powder }}$ kg), its dry extract $\left(D E_{\text {powder }} ; \mathrm{kg}_{\text {solid }} \cdot \mathrm{kg}_{\text {concentrated milk }}^{-1}\right)$, and the total time of the drying process $(t ; \mathrm{h})$ :

$$
M_{\mathrm{ts}, \text { out }}=\left(\frac{M_{\mathrm{p}} \mathrm{TS}_{\mathrm{p}}}{t}\right)
$$

The mass balance is calculated as the difference between the amount of solids recovered after drying $\left(M_{\text {total solid,out; }}\right.$ Eq. 21$)$ and mass of solids injected into equipment ( $M_{\text {total solid,in }}$ Eq. 20$)$ :

$$
\begin{aligned}
& \Delta_{\text {mass }}=M_{\mathrm{ts}, \text { out }}-M_{\mathrm{ts}, \text { in }} \\
& \Delta_{\text {mass }}=\left(\frac{M_{\mathrm{p}} T S_{\mathrm{p}}}{t}\right)-F_{\text {milk,inj }} \mathrm{TS}_{\mathrm{m}}
\end{aligned}
$$

In an ideal drying process, all solids entering into system should be recovered after drying; however, in milk drying, a considerable part of the powder is lost in the air flow or adhered to the drying tower. The mass of milk powder lost ( $M_{\text {loss}}$, in percentage) can be calculated as

$$
M_{\text {loss }}=\left(1-\frac{M_{\mathrm{ts}, \mathrm{out}}}{M_{\mathrm{ts}, \text { in }}}\right) \times 100
$$

Substitution of Eqs. (21) and (22) into (23) yields:

$$
M_{\mathrm{loss}}=\left(\frac{1-M_{\mathrm{p}} \mathrm{TS}_{\mathrm{p}}}{t F_{\mathrm{m}, \mathrm{inj}} \mathrm{TS}_{\mathrm{m}}}\right) \times 100
$$

Table 4 shows the inlet and outlet data necessary to calculate the loss of mass for milk drying.

The negative sign of $\Delta_{\text {mass }}$ indicates that part of the milk solids were lost during drying. Another relevant factor for mass loss is the dissipation of powder together with the outlet air, and this loss increases based on how

\begin{tabular}{|c|c|c|c|c|c|c|c|}
\hline \multirow[b]{2}{*}{ Equipment } & \multicolumn{2}{|c|}{ Inlet data } & \multicolumn{3}{|c|}{ Outlet data } & \multirow[b]{2}{*}{$\Delta_{\text {mass }}(\mathrm{kg})$} & \multirow[b]{2}{*}{$M_{\text {loss }}(\%)$} \\
\hline & $F_{\text {milk,inj }} *\left(\mathrm{~kg} \mathrm{~h}^{-1}\right)$ & $D E_{\text {milk }} *\left(\mathrm{~kg} \mathrm{~kg}^{-1}\right)$ & $M_{\text {powder }} *(\mathrm{~kg})$ & $D E_{\text {powder }} *\left(\mathrm{~kg} \mathrm{~kg}^{-1}\right)$ & $t^{*}(\mathrm{~h})$ & & \\
\hline SD1 & $1.24 \times 10^{0}$ & $3.83 \times 10^{-1}$ & $2.92 \times 10^{-1}$ & $9.55 \times 10^{-1}$ & $6.67 \times 10^{-1}$ & -0.06 & 12 \\
\hline SD2 & $1.83 \times 10^{1}$ & $3.83 \times 10^{-1}$ & $1.46 \times 10^{0}$ & $9.56 \times 10^{-1}$ & $2.73 \times 10^{-1}$ & -1.90 & 26 \\
\hline
\end{tabular}
much finer the powder is. Lab-scale equipment produces finer particles than industrial equipment, and the spray dryers utilized in this experiment are compounds with a unique stage drying that increases

Table 4. Mass balance for milk drying.

*Measurement performed in triplicate with standard variation inferior to $5 \%$. 
Table 5. Energetic balance for milk drying.

\begin{tabular}{|c|c|c|c|c|c|c|c|c|c|c|c|c|}
\hline \multirow[b]{2}{*}{ Equipment } & \multicolumn{4}{|c|}{ Inlet data } & \multicolumn{5}{|c|}{ Outlet data } & \multirow[b]{2}{*}{$\begin{array}{c}\varepsilon_{\text {loss }} \\
(\%)\end{array}$} & \multirow[b]{2}{*}{$\begin{array}{c}\text { ESC } \\
\left(\mathrm{kJ} \mathrm{kg}^{-1}\right)\end{array}$} & \multirow[b]{2}{*}{$\varepsilon_{\text {efficiency }}$} \\
\hline & $\begin{array}{c}T^{\circ} \mathrm{C}_{\text {air,in }} * \\
\left({ }^{\circ} \mathrm{C}\right)\end{array}$ & $\begin{array}{c}A H_{\mathrm{in}}^{*} \\
\left(\mathrm{~kg}_{\text {water }} \cdot \mathrm{kg}_{\text {dry air }}^{-1}\right)\end{array}$ & $\begin{array}{c}T^{\circ} \mathrm{C}_{\text {milk,inj }}{ }^{*} \\
\left({ }^{\circ} \mathrm{C}\right)\end{array}$ & $\begin{array}{c}\varepsilon_{\text {total,in }} \\
\left(\mathrm{kJ} \mathrm{h}^{-1}\right)\end{array}$ & $\begin{array}{c}V_{\text {air,out }}{ }^{*} \\
\left({ }^{\circ} \mathrm{C}\right)\end{array}$ & $A_{\text {out }}\left(\mathrm{m}^{2}\right)$ & $\begin{array}{c}A H_{\text {out }} * \\
\left(\mathrm{~kg}_{\text {water }} \cdot \mathrm{kg}_{\text {dry air }}^{-1}\right)\end{array}$ & $\begin{array}{c}T^{\circ} \mathrm{C}_{\text {air,out }}{ }^{*} \\
\left({ }^{\circ} \mathrm{C}\right)\end{array}$ & $\begin{array}{l}\varepsilon_{\text {total,out }} \\
\left(\mathrm{kJ} \mathrm{h}^{-1}\right)\end{array}$ & & & \\
\hline SD1 & $1.62 \times 10^{2}$ & $1.59 \times 10^{-2}$ & $4.0 \times 10^{1}$ & $1.11 \times 10^{4}$ & $5.65 \times 10^{4}$ & $9.62 \times 10^{-4}$ & $3.07 \times 10^{-2}$ & $9.76 \times 10^{1}$ & $9.68 \times 10^{3}$ & 13.89 & $1.52 \times 10^{4}$ & 6.55 \\
\hline SD2 & $1.70 \times 10^{2}$ & $1.36 \times 10^{-2}$ & $3.9 \times 10^{1}$ & $9.82 \times 10^{4}$ & $6.55 \times 10^{4}$ & $7.24 \times 10^{-3}$ & $3.80 \times 10^{-2}$ & $8.84 \times 10^{1}$ & $9.04 \times 10^{4}$ & 10.72 & $9.19 \times 10^{3}$ & 3.93 \\
\hline
\end{tabular}

* Measurement performed in triplicate with standard variation inferior to $5 \%$

the formation of these fine powders and consequently their loss. ${ }^{[22,23]}$

\section{Energy balance for milk drying}

The energy balance for milk drying is very similar to that shown for water evaporation and it was previously described. ${ }^{[24-26]}$ However, instead of the parameters for water, the data for concentrated milk will be used. Using Eq. (14) as a base, the energy entering during the drying process can be rewritten as:

$$
\begin{gathered}
\varepsilon_{\mathrm{t}, \text { in }}=\left[\mathrm{T}_{\mathrm{a}, \text { in }}\left(1.01+1.89 A H_{\text {in }}\right)+2500 A H_{\text {in }}\right] \\
{\left[V_{\mathrm{a}, \text { out }} A_{\text {out }} \rho\left(1+A H_{\text {out }}\right)^{-1}\right]+F_{\mathrm{m}, \text { inj }} C p_{\mathrm{m}} T_{\mathrm{m}, \text { inj }}}
\end{gathered}
$$

where $C p_{\text {milk }}$ corresponds to the specific heat of milk in $\mathrm{kJ} \mathrm{kg}^{-1}$ and $T^{\circ} \mathrm{C}_{\text {milk,inj }}$ is the temperature of concentrated milk in ${ }^{\circ} \mathrm{C}$.

$C p_{\text {milk }}$ is estimated by the following relation: ${ }^{[3]}$

$$
C p_{\mathrm{m}}=\left(1-0.56 \mathrm{TS}_{\mathrm{m}}\right) 4.186
$$

where $C p_{\text {milk }}$ corresponds to the specific heat of milk in $\mathrm{kJ} \mathrm{kg}^{-1}$, the equation $1-0.56 \times D E_{\text {milk }}$ refers the meanspecific heat of the milk solid components, which is established as $44 \%$ of the specific heat of water (4.186) and $D E_{\text {milk }}$ is the dry mass of the milk.

Substitution of Eq. (26) into Eq. (25) yields:

$$
\begin{aligned}
\varepsilon_{\mathrm{t}, \text { in }}= & {\left[\mathrm{T}_{\mathrm{a}, \text { in }}\left(1.01+1.89 A H_{\text {in }}\right)+2500 A H_{\text {in }}\right] } \\
& \times\left[V_{\mathrm{a}, \text { out }} A_{\text {out }} \rho\left(1+A H_{\text {out }}\right)^{-1}\right]+\left[\left(1-0.56 T S_{\mathrm{m}}\right)\right. \\
& \times 4.186] F_{\mathrm{m}, \text { inj }} T_{\mathrm{m}, \text { inj }}
\end{aligned}
$$

The outlet energy $\left(\varepsilon_{\text {out }} ; \mathrm{kJ} \mathrm{h}^{-1}\right)$ can be calculated from Eq. (15) by adapting the parameters for milk powder:

$$
\begin{aligned}
\varepsilon_{\mathrm{t}, \text { out }}= & {\left[\mathrm{T}_{\mathrm{a}, \text { out }}\left(1.01+1.89 A H_{\text {out }}\right)+2500 A H_{\text {out }}\right] } \\
& {\left[V_{\mathrm{a}, \text { out }} A_{\text {out }} \rho\left(1+A H_{\text {out }}\right)^{-1}\right] } \\
& +\left[\frac{M_{\mathrm{p}}}{t} C p_{\mathrm{p}}\left(\mathrm{T}_{\mathrm{a}, \text { out }}-20\right)\right]
\end{aligned}
$$

where $M_{\text {powder }}$ and $C p_{\text {powder }}$ correspond to the rate of powder production in $\mathrm{kg} \mathrm{h}^{-1}$ and the specific heat of the powder $\left(\mathrm{kJ} \mathrm{kg}^{-1} \cdot{ }^{\circ} \mathrm{C}^{-1}\right)$, respectively. Note that the temperature of powder in the outlet of equipment was estimated as the temperature of outlet air
$\left(T^{\circ} \mathrm{C}_{\text {air,out }}\right.$ ) subtracted from $20^{\circ} \mathrm{C}$. The temperature of the particle during spray drying is between the outlet air temperature and wet-bulb temperature of the outlet air, which means $10-20^{\circ} \mathrm{C}$ below the outlet air temperature. ${ }^{[27,28]}$

Replacing $C p_{\text {powder }}$ in Eq. (28) by its correspondent relation (Eq. 26) yields:

$$
\begin{aligned}
\varepsilon_{\mathrm{t}, \text { out }}= & {\left[\mathrm{T}_{\mathrm{a}, \text { out }}\left(1.01+1.89 A H_{\text {out }}\right)+2500 A H_{\text {out }}\right] } \\
& \times\left[V_{\mathrm{a}, \text { out }} A_{\text {out }} \rho\left(1+A H_{\text {out }}\right)^{-1}\right] \\
& +\left[\left(1-0.56 T S_{\mathrm{p}}\right) 4.186\right] \frac{M p}{t}\left(\mathrm{~T}_{\mathrm{a}, \text { out }}-20\right)
\end{aligned}
$$

The energy loss $\left(\varepsilon_{\text {loss }}\right)$, ESC for milk, and energetic efficiency of process $\left(\varepsilon_{\text {efficiency }}\right)$ are also calculated for drying milk from Eqs. (17)-(19), respectively.

Tables 4 and 5 list the parameters needed to calculate the energy balance for milk drying.

For spray dryers SD1 and SD2, the energetic losses $\left(\varepsilon_{\text {loss }}\right)$ were approximately 1.1 and 1.2 times higher than the energetic losses for water evaporation (Table 3 ). These differences between milk drying and ideal drying (water evaporation) are directly related to powder mass lost during the process and the larger energy necessary to evaporate the water from food. ${ }^{[20,29]}$

\section{Conclusion}

The mathematical model was valid for evaluation of the mass and energy losses, and it allowed a comparison of the efficiency between spray dryers with different designs. Using this model, it is possible to compare different drying processes and dryers. Spray dryer SD2 showed higher energy efficiency than SD1. Application of this protocol of calculus to industrial processes should measure the air flow rate, area of transversal section of outlet air tubing, air velocity, absolute humidity of the air (inlet and outlet), temperature (water or milk, inlet and outlet air), and mass (water or milk, powder).

\section{Funding}

The authors thank the Brazilian agencies FAPEMIG, CNPq, and CAPES for financial support. 


\section{ORCID}

Antônio Fernandes de Carvalho (D) http://orcid.org/00000002-3238-936X

\section{References}

[1] CNIEL. The world dairy situation 2015. Bulletin of the international dairy federation 2015, 481.

[2] Ciurzyńska, A.; Lenart, A. Freeze-drying - Application in food processing and biotechnology - A review. Polish Journal of Food and Nutrition Sciences 2011, 61, 165-171.

[3] Schuck, P.; Jeantet, R.; Tanguy, G.; Méjean, S.; Gac, A.; Lefebvre, T.; Labussiere, E.; Martineau, M. Energy consumption in the processing of dairy and feed powders by evaporation and drying. Drying Technology 2015, 33, 176-184.

[4] Walstra, P.; Wouters, J.T.M.; Geurts, T.J. Dairy Science and Technology; CRC Press: New York, 2006.

[5] Juming, T.; Feng, H.; Shen, G.-Q. Drum drying. In Encyclopedia of Agricultural, Food, and Biological Engineering; Heldman, Dennis R. ed.; Heldman Associates: San Marcos, 2003.

[6] Schuck, P.; Dolivet, A.; Mejean, S.; Hervé, C.; Jeantet, R. Spray-drying of dairy bacteria: New opportunities to improve the viability of bacteria powders. International Dairy Journal 2013, 31(1), 12-17.

[7] Gharsallaoui, A.; Roudaut, G.; Chambin, O.; Voilley, A.; Saurel, R. Applications of spray-drying in microencapsulation of food ingredients: An overview. Food Research International 2007, 40(9), 1107-1121.

[8] Mujumdar, A.S.; Huang, L.X.; Chen, X.D. An overview of the recentadvances in spray-drying. Dairy Science and Technology 2010, 90, 211-224.

[9] Ozmen, L.T.A.G.; Langrish, T.A.G. A study of the limitations to spray dryer outlet performance. Drying Technology 2003, 21, 895-917.

[10] Shrestha, A.K.; Howes, T.; Adhikari, B.P.; Bhandari, B.R. Spray drying of skim milk mixed with milk permeate: Effect on drying behavior, physicochemical properties, and storage stability of powder. Drying Technology 2008, 26, 239-247.

[11] Birchal, V.S.; Passos, M.L.; Wildhagen, G.R.; Mujumdar, A.S. Effect of spray-dryer operating variables on the whole milk powder quality. Drying Technology 2005, 23(3), 611-636.

[12] Schuck, P.; Dolivet, A.; Jeantet, R. Analytical Methods for Food and Dairy Powders; Wiley-Blackwell: Chichester, 2012.

[13] Schuck, P.; Jeantet, R.; Bhandari, B.; Chen, X.D.; Perrone, I.T.; Carvalho, A.F.; Fenelon, M.; Kelly, P. Recent advances in spray drying relevant to the dairy industry: A comprehensive critical review. Drying Technology 2016, 34, 1773-1790.

[14] O’Donnell, C.P.; McKenna, B.M.; Herlihy, N. Drying of skim milk: Opportunities for reducted steam. Drying Technology 1996, 14, 513-528.

[15] Zhu, P.; Méjean, S.; Blanchard, E.; Jeantet, R.; Schuck, P. Prediction of dry mass glass transition temperature and the spray-drying behaviour of a concentrate using a desorption method. Journal of Food Engineering 2011, 105(3), 460-467.

[16] Defraeye, T. Advanced computational modelling for drying processes - A review. Applied Energy 2014, 131, 323-344.

[17] Jin, Y.; Chen, X.D. A three-dimensional numerical study of the gas/particle interactions in an industrial-scale spray dryer for milk powder production. Drying Technology 2009, 27(10), 1018-1027.

[18] Masters, K. Spray-Drying; Longman Scientific \& Technical and John Wiley \& Sons Inc.: New York, 2002.

[19] Schuck, P.; Blanchard, E.; Dolivet, A.; Méjean, S.; Onillon, E.; Jeantet, R. Water activity and glass transition in dairy ingredients. Lait 2005, 85, 295-304.

[20] Cox, M.M.; Nelson, D.L. Lehninger Principles of Biochemistry; W. H. Freeman \& Co. Ltd: New York, 2005.

[21] Bimbenet, J.J.; Schuck, P.; Roignant, M.; Brule, G.; Méjean, S. Heat balance of a multistage spray-dryer: Principles and example of application. Lait 2002, 82(4), 541-551.

[22] Zhu, P.; Jeantet, R.; Dolivet, A.; Méjean, S.; Schuck, P. Caractérisation du comportement d'une tour de séchage pilote: Bilans massiques et thermiques. Industries Alimentaires et Agricoles 2009, 126, 23-29.

[23] Donz, E.; Boiron, P.; Courthaudon, J. Characterization of industrial dried whey emulsions at different stages of spray-drying. Journal of Food Engineering 2014, 126, 190-197.

[24] Kudra, T. Energy aspects in drying. Drying Technology 2004, 22(5), 917-932.

[25] Baker, C.G.J.; McKenzie, K.A. Energy consumption of industrial spray dryers. Drying Technology 2005, 23(1-2), 365-386.

[26] Baker, C.G.J. Energy efficient dryer operation-An update on developments. Drying Technology 2005, 23(9-11), 2071-2087.

[27] Písecký, I.J. Handbook of Milk Powder Manufacture; NIRO A/S: Copenhagen, 1997.

[28] Westergaard, V. Milk powder technology. In Evaporation and Spray-Drying; GEA Niro A/S: Copenhagen, 2001.

[29] Bhandari, B.R.; Howes, T. Implication of glass transition for the drying and stability of dried foods. Journal of Food Engineering 1999, 40(1-2), 71-79. 